CARDOSO, AII; CLAUDIO, MTR; NAKADA-FREITAS, PG; MAGRO, FO; TAVARES, AEB. 2016. Phosphate fertilization over the accumulation of macronutrients in cauliflower seed production. Horticultura Brasileira 34: 196-201. DOI - http://dx.doi.org/10.1590/S0102-053620160000200008

\title{
Phosphate fertilization over the accumulation of macronutrients in cauliflower seed production
}

\author{
Antonio II Cardoso후 Marina TR Claudio²; Pâmela G Nakada-Freitas ${ }^{3}$; Felipe O Magro ${ }^{4}$; Ana EB \\ Tavares $^{1}$ \\ ${ }^{1}$ Universidade Estadual Paulista (UNESP-FCA), Botucatu-SP, Brasil; ismaeldh@fca.unesp.br; anaemiliatavares@yahoo.com.br; ${ }^{2}$ Sakata \\ Seed Sudamerica Ltda; Bragança Paulista-SP, Brasil; marina.toledo@sakata.com.br; ${ }^{3}$ Universidade Estadual Paulista (UNESP/FCAT), \\ Dracena-SP, Brasil; pamelanakada@dracena.unesp.br; ${ }^{4}$ Prefeitura de Jundiaí, Jundiaí-SP, Brasil; felipe_magro@yahoo.com.br
}

\begin{abstract}
Considering the scarce information on nutrient extraction by plants for seed production within vegetable crops, as well as the effect of fertilization over extraction, studying nutrient accumulation in different plant parts under varied fertilization rates is necessary. This study aimed to evaluate the influence of phosphate rates on macronutrient accumulation in cauliflower plants during seed production. Five phosphate rates were studied (0, 300, 600, 900 and $1200 \mathrm{~kg} / \mathrm{ha} \mathrm{P}_{2} \mathrm{O}_{5}$ ), in a randomized complete block design, with four replications. Accumulation of nutrients in the different plant parts was evaluated at the end of the cycle (vegetative and reproductive, the latter divided in seeds and inflorescence). Data were submitted to analysis of variance and regression. Considering only the seeds, a quadratic effect was obtained for the accumulation of all macronutrients, with maximum estimated for rates between 858 and $952 \mathrm{~kg} / \mathrm{ha} \mathrm{P}_{2} \mathrm{O}_{5}$. Considering the whole plant (total accumulation), a linear increase for $\mathrm{P}, \mathrm{Ca}$ and $\mathrm{S}$ was obtained the higher the $\mathrm{P}_{2} \mathrm{O}_{5}$ rates, while the effect was quadratic for $\mathrm{N}, \mathrm{K}$ and $\mathrm{Mg}$ accumulation. The total nutrient accumulation descending order was: $\mathrm{K}>\mathrm{N}>\mathrm{Ca}>\mathrm{S}>\mathrm{P}>\mathrm{Mg}$, and considering only the seeds was: $\mathrm{N}>\mathrm{S}>\mathrm{K}>\mathrm{P}>\mathrm{Ca}>\mathrm{Mg}$, $\mathrm{S}$ being highlighted as the second most accumulated nutrient in the seeds.
\end{abstract}

Keywords: Brassica oleracea var. botritys, phosphorus, mineral nutrition.

\section{RESUMO}

Adubação fosfatada no acúmulo de macronutrientes em plantas de couve-flor destinadas à produção de sementes

Devido à escassez de informações relacionadas à quantidade de nutrientes extraídos pelas plantas na produção de sementes de hortaliças e o efeito da adubação nesta extração, nota-se a necessidade de se estudar o acúmulo de nutrientes nos diferentes órgãos das plantas quando se varia a adubação no plantio. Por isto, objetivou-se avaliar a influência de doses de fósforo no acúmulo de macronutrientes em plantas de couve-flor destinadas à produção de sementes. Foram estudadas cinco doses de fósforo $(0,300,600,900$ e $1200 \mathrm{~kg} / \mathrm{ha}$ de $\mathrm{P}_{2} \mathrm{O}_{5}$ ), no delineamento experimental em blocos ao acaso, com quatro repetições. Foi avaliado o acúmulo de macronutrientes nos diferentes órgãos da planta ao final do ciclo (parte vegetativa e reprodutiva, sendo esta dividida em sementes e restos da inflorescência). Os dados foram submetidos às análises de variância e de regressão. Ao se considerar apenas as sementes, o acúmulo de todos os nutrientes ajustou-se ao modelo quadrático, com máximos acúmulos estimados para doses entre 858 e $952 \mathrm{~kg} /$ ha de $\mathrm{P}_{2} \mathrm{O}_{5}$. Ao se considerar a planta inteira (acúmulo total), foram obtidos aumentos lineares para $\mathrm{P}, \mathrm{Ca}$ e $\mathrm{S}$ quanto maior a dose de fósforo, enquanto que para o acúmulo de $\mathrm{N}, \mathrm{K}$ e Mg o efeito foi quadrático. A ordem decrescente do acúmulo total de nutrientes foi: $\mathrm{K}>\mathrm{N}>\mathrm{Ca}>\mathrm{S}>\mathrm{P}>\mathrm{Mg}$, e pelas sementes foi: $\mathrm{N}>\mathrm{S}>\mathrm{K}>\mathrm{P}>\mathrm{Ca}>\mathrm{Mg}$, com destaque para o $\mathrm{S}$ que foi o segundo mais acumulado nas sementes.

Palavras-chave: Brassica oleracea var. botrytis, fósforo, nutrição mineral.

(Recebido para publicação em 8 de dezembro de 2014; aceito em 15 de outubro de 2015) (Received on December 8, 2014; accepted on October 15, 2015)

\begin{abstract}
A lthough studies on nutrition and fertilization for growing cauliflower and other leafy vegetables can be found in literature, studies on the effect of fertilizer on seed production and, mainly, on the accumulation of nutrients, in species which present an increase in the cycle (Cardoso, 2011), as for Brassicaceae are scarce.

In cauliflower, the amounts of nutrients required for seed production
\end{abstract}

might be different from those employed for commercial production, since the crop has a higher development cycle, formation of new structures, flowers and seeds, and probably a greater nutrient uptake. In broccoli, which is of the same species as cauliflower, Magro et al. (2009) reported, for seed production, higher extraction of all the macronutrients in relation to commercial cultivation. Kano et al. (2006, 2012),
Magro et al. (2010) and Quadros et al. (2012) reported that the amounts of nutrients required for seed production is higher than for obtaining commercial product in species which show longer cycle. Carvalho \& Nakagawa (2012) highlight that nutritional requirement for most species becomes more intense at the beginning of the reproductive stage, being more critical during the seed formation, when considerable amounts 
of nutrients are translocated to them.

Some authors have reported that the most accumulated nutrients in cauliflower are nitrogen $(\mathrm{N})$ and potassium (K) (Homa et al., 1969; Furlani et al., 1978; Filgueira, 2008; Castoldi et al., 2009; Takeishi et al., 2009; Alves et al., 2011). However, according to Akhtar et al. (2008), Filgueira (2008), Dhakal et al. (2009), Hammond et al. (2009), Islam et al. (2010) and Elahi et al. (2015), phosphorus (P) has been one of the nutrients which has provided major responses in increasing productivity in brassicas. However, researches on phosphate fertilization in production of cauliflower seeds were not found in literature and studies on the commercial production of this crop cannot be extrapolated to seed production, since the crop has a much higher development cycle and nutrient requirement might also be much higher.

Due to the scarcity of information related to the extraction of nutrients for cauliflower seed production, and the effect of fertilization over extraction, studies are necessary on the accumulation and distribution of nutrients among the different plant organs. Knowledge of nutrient accumulation by the plants may be useful for fertilization management in seed production fields, aiming to a balanced replacement of the extracted macronutrients. Therefore, this study aimed to evaluate the influence of phosphorus $(\mathrm{P})$ rates on the accumulation of macronutrients in cauliflower for seed production.

\section{MATERIAL AND METHODS}

This experiment was carried out at the Experimental Farm São Manuel, located in the municipality of São Manuel, São

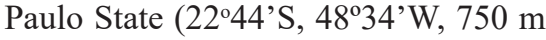
elevation). The local climate is $\mathrm{Cfa}$, according to Köppen classification, hot temperate (mesothermal) humid, with average annual rainfall $1377 \mathrm{~mm}$ (Cunha \& Martins, 2009).

Plants were carried out in a greenhouse, arch type, covered with transparent polyethylene of low density (LDPE), $150 \mu \mathrm{m}$ thickness, $20 \mathrm{~m}$ length,
$7 \mathrm{~m}$ width, $1.8 \mathrm{~m}$ ceiling height, which remained with open sides in order to allow the entrance of pollinators.

Soil was a Dystrophic Red Latosol, the following results being obtained in the chemical analysis, prior to the experiment: $\mathrm{pH}_{(\mathrm{CaCl} 2)}=5.8 ; \mathrm{P}_{\text {resyn }}=11$ $\mathrm{mg} / \mathrm{dm}^{3}$; organic matter $=5 \mathrm{~g} / \mathrm{dm}^{3} ; \mathrm{V}=$ $74 \%$; and the values of $\mathrm{H}+\mathrm{Al} ; \mathrm{K}$; $\mathrm{Ca}$; $\mathrm{Mg}$; sum of basis and $\mathrm{CEC}$, expressed in $\mathrm{mmol} / \mathrm{dm}^{3}$, respectively of: $11 ; 2.2$; $21 ; 8 ; 31$ and 42 . According to these results, the initial $\mathrm{P}$ content in the soil $\left(11 \mathrm{mg} / \mathrm{dm}^{3}\right)$ is considered low (Raij et al., 1997).

Liming was carried out based on the soil chemical analysis, aiming to raise base saturation (V) to $80 \%$. Fertilization at planting consisted of the supply of $60 \mathrm{~kg} / \mathrm{ha} \mathrm{N}$ and $240 \mathrm{~kg} / \mathrm{ha} \mathrm{K}_{2} \mathrm{O}$, as recommended by Raij et al. (1997), applied in the form of ammonium sulfate and potassium chloride, respectively, in addition to organic fertilization, which corresponded to $20 \mathrm{t} / \mathrm{ha}$ of organic compost Provaso ${ }^{\circledR}$. The chemical analysis of the compost showed $\mathrm{pH}$ values of 8.2 and values of organic matter; $\mathrm{N} ; \mathrm{P}_{2} \mathrm{O}_{5} ; \mathrm{K}_{2} \mathrm{O} ; \mathrm{Ca} ; \mathrm{Mg}$ and $\mathrm{S}$, expressed in $\%$ of dry matter, respectively $13.3 ; 0.43 ; 0.62 ; 0.48 ; 1.61$; 0.17 and 0.20 . The $\mathrm{C} / \mathrm{N}$ ratio was $19 / 1$ and the compost water content $38 \%$.

Five treatments were evaluated (rates of phosphorus) in randomized blocks with four replications and three useful plants per plot. The rate $600 \mathrm{~kg} /$ ha $\mathrm{P}_{2} \mathrm{O}_{5}$, recommended by Raij et al. (1997) for the production of cauliflower considering a low $\mathrm{P}$ content in the soil $\left(11 \mathrm{mg} / \mathrm{dm}^{3}\right)$ was considered for defining treatments $\mathrm{T} 0$ : treatment without $\mathrm{P}$ application (zero rate); $\mathrm{T} 300$ : half $\mathrm{P}$ recommended rate; $\mathrm{T} 600$ : the recommended rate; T900: one and half times the recommended rate and T1200: twice the recommended dose. Triple superphosphate $\left(42 \% \mathrm{P}_{2} \mathrm{O}_{5}\right)$ was used as $\mathrm{P}$ source.

The cultivar Piracicaba Precoce was used. Sowing was carried out on March 01, 2011 in polypropylene trays of 162 cells, containing commercial substrate for vegetable seedling production. Seedlings were transplanted on March 31,2011 into pots with a volume of 13 $\mathrm{L}$, one plant being cultivated per pot, spaced $1.0 \mathrm{~m}$ between rows and $0.5 \mathrm{~m}$ between plants (center to center of the pots).

Top dress application of nitrogen $(200 \mathrm{~kg} / \mathrm{ha} \mathrm{N})$ and potassium $(100 \mathrm{~kg} /$ ha $\mathrm{K}_{2} \mathrm{O}$ ), divided into three applications, on April 08 and 20 and May 12, 2011, using ammonium sulphate $(21 \% \mathrm{~N})$ and potassium chloride $\left(60 \% \mathrm{~K}_{2} \mathrm{O}\right)$, respectively. In seedling phase, spray applications with boric acid $(1 \mathrm{~g} / \mathrm{L})$ and sodium molybdate $(1 \mathrm{~g} / \mathrm{L})$ were carried out, as well as at 15 and 16 days after seedling transplanting, respectively.

Plants were tutored, in order to prevent tipping in the reproductive phase, and pest control was carried out according to the needs of the crop. Drip irrigation was used.

Seed harvesting was performed when approximately $50 \%$ of siliques from each plant were yellowish, not completely dry, and the seeds showed dark brown or black color (Contreras et al., 2014). First, the authors separated all the vegetative fractions of the inflorescences, obtaining the first sample of each plant. The seeds (along with the rest of the floral parts) were taken to a drying chamber at $40 \%$ relative humidity and at temperature of $20^{\circ} \mathrm{C}$, to better preserve them up to the end of harvesting. After treshing, seeds were submitted to a cleaning process in order to remove the empty and damaged ones, using a seed density separator device (model 'De Leo Type 1', calibrated in an opening corresponding to $15 \%$ of the air outlet area), obtaining, thus, the classified seeds, according to methodology of Magro et al. (2010). After this cleaning process, two samples were obtained: one sample with classified seeds and another with all the remaining material (rest of inflorescence and fruits, siliques) called "inflorescence".

After obtaining each sample (vegetative part, seeds and inflorescence) they were washed with mild detergent and running water and, then, with distilled water. After removing the excess of water, samples were packed in paper bags, identified and taken to be dried in forced air circulation at $65^{\circ} \mathrm{C}$, until they reached constant mass, according to Malavolta et al. (1997). 
After drying, the samples were weighed in order to obtain dry matter mass.

After grinding (Willey type mill), the samples were taken to the Department of Soil and Environmental Resources of UNESP, for chemical analyses. Sulfuric acid digestion was used to obtain the extract for determining $\mathrm{N}$. Nitric-perchloric digestion was used to obtain extracts to determine the other macronutrients $(\mathrm{P}, \mathrm{K}, \mathrm{Ca}, \mathrm{Mg}$ and $\mathrm{S}$ ), according to the methodologies presented by Malavolta et al. (1997).

Based on the chemical analyses, the authors obtained contents of N, P, K, $\mathrm{Ca}, \mathrm{Mg}$ and $\mathrm{S}$ in $\mathrm{g} / \mathrm{kg}$. The amount of nutrients accumulated in each sample was obtained by multiplying each sample content by the dry matter mass of the sample.

After these procedures, the following chemical characteristics were determined: macronutrient accumulation in the vegetative part at the end of the cycle, in the seeds, in the reproductive part (seeds + inflorescence) and total (vegetative + reproductive parts).

Data were subjected to analysis of variance and regression to verify the effect of rates of phosphorus in traits evaluated. Original data were processed by Sisvar version 5.0.

\section{RESULTS AND DISCUSSION}

In vegetative part, for $\mathrm{P}, \mathrm{Ca}, \mathrm{Mg}$ and $\mathrm{S}$ accumulation, linear effect was obtained (Figures 1 and 2), with an increase of $16.9,64.8,4.9$ and $3.2 \mathrm{mg} /$ plant for each $100 \mathrm{~kg} /$ ha $\mathrm{P}_{2} \mathrm{O}_{5}$, respectively. For $\mathrm{N}$ and $\mathrm{K}$, quadratic effect was obtained, with maximum accumulation estimated in 418 and $1523 \mathrm{mg} / \mathrm{plant}$, with rates of 724 and $851 \mathrm{~kg} / \mathrm{ha} \mathrm{P}_{2} \mathrm{O}_{5}$, respectively. Ding et al. (2010) reported that correlation between the availability of phosphorus and macronutrient absorption by plants is noticed, so, the higher phosphorus availability, especially in poor soil, the greater the accumulation of nutrients by plants.

The vegetative part was formed by stem and old leaves already senescent, which have already detached from the plant, it means, the highest accumulated part had no role in the plant at the time

Table 1. Distribution of macronutrients (\%) accumulated at several parts of the cauliflower plant at the end of the plant cycle (distribuição percentual do acúmulo de macronutrientes nas diversas partes da planta de couve-flor no final do ciclo). São Manuel, UNESP, 2011.

\begin{tabular}{lccrrcc}
\hline Plant part & P & N & K & Ca & Mg & S \\
\hline Vegetative & 23.6 & 13.8 & 26.1 & 57.8 & 43.3 & 13.1 \\
Reproductive & 76.4 & 86.2 & 73.9 & 42.2 & 56.7 & 86.9 \\
Seeds & 24.9 & 29.0 & 3.0 & 2.8 & 14.8 & 29.6 \\
Stems & 51.5 & 57.2 & 70.9 & 39.4 & 41.9 & 57.3 \\
\hline
\end{tabular}

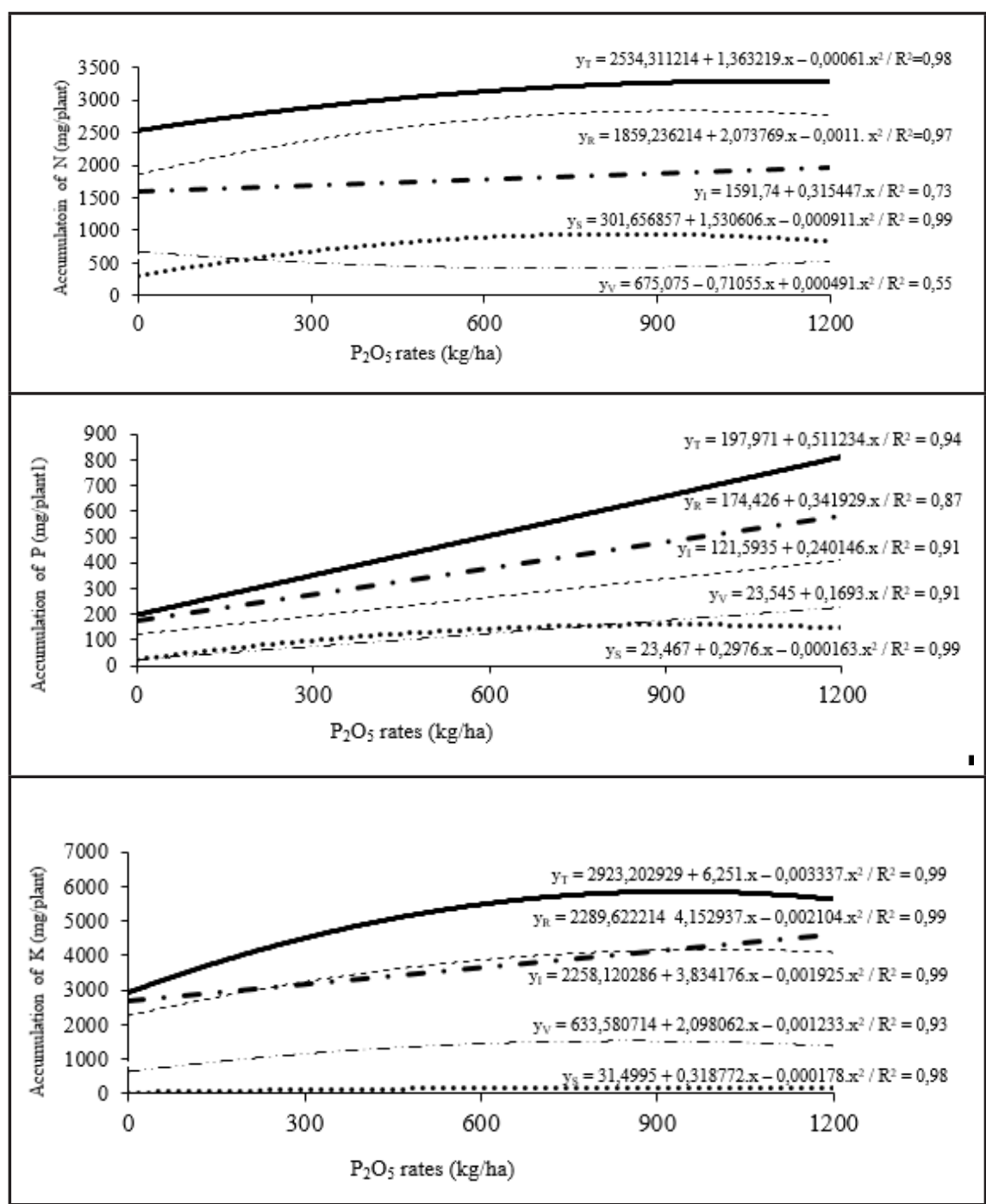

Figure 1. Nitrogen $(\mathrm{N})$, phosphorus $(\mathrm{P})$ and potassium $(\mathrm{K})$ accumulation in vegetative part $\left(\mathrm{y}_{\mathrm{v}}\right)$, inflorescence $\left(\mathrm{y}_{\mathrm{I}}\right)$, seeds $\left(\mathrm{y}_{\mathrm{s}}\right)$, total reprodutive part (seeds + inflorescence) $\left(\mathrm{y}_{\mathrm{R}}\right)$ and all cauliflower plant $\left(\mathrm{y}_{\mathrm{T}}\right)$, depending on phsphorus $\left(\mathrm{P}_{2} \mathrm{O}_{5}\right)$ rates, at the end of cycle acúmulo de nitrogênio $(\mathrm{N})$, fósforo $(\mathrm{P})$ e potássio $(\mathrm{K})$ na parte vegetativa $\left(\mathrm{y}_{\mathrm{v}}\right)$, na inflorescência $\left(\mathrm{y}_{\mathrm{I}}\right)$, sementes $\left(\mathrm{y}_{\mathrm{s}}\right)$, total reprodutivo (sementes + inflorescência) $\left(\mathrm{y}_{\mathrm{R}}\right)$ e total $\left(\mathrm{y}_{\mathrm{T}}\right)$ na planta de couveflor, em função das doses de fósforo $\left(\mathrm{P}_{2} \mathrm{O}_{5}\right)$, no final do ciclo\}. São Manuel, UNESP, 2011.

of sampling. The descending order of accumulation in this vegetative part was: $\mathrm{Ca}>\mathrm{K}>\mathrm{N}>\mathrm{Mg}>\mathrm{P}>\mathrm{S}$.

In reproductive part linear effect was obtained for P, Ca and S (Figures
1 and 2), with an increase of 34.2, 48.7 and $17.5 \mathrm{mg} / \mathrm{plant}$ for each $100 \mathrm{~kg} / \mathrm{ha}$ $\mathrm{P}_{2} \mathrm{O}_{5}$, respectively. For $\mathrm{N}, \mathrm{K}$ and $\mathrm{Mg}$, quadratic effect was obtained, with maximum accumulation estimated 
in 2837, 4339 and $234 \mathrm{mg} /$ plant, for rates 943,987 and $848 \mathrm{~kg} / \mathrm{ha} \mathrm{P}_{2} \mathrm{O}_{5}$, respectively. The descending order of accumulation in this reproductive part was: $\mathrm{K}>\mathrm{N}>\mathrm{Ca}>\mathrm{S}>\mathrm{P}>\mathrm{Mg}$.

By isolating only the seeds, the results differ somewhat from the overall reproductive. In this situation, quadratic effect was obtained for all macronutrients (Figures 1 and 2). Maximum accumulation were estimated in $945,159,174,84,61$ and $204 \mathrm{mg} /$ plant, with rates of $840,913,895$, 858,875 and $952 \mathrm{~kg} / \mathrm{ha} \mathrm{P}_{2} \mathrm{O}_{5}$, for $\mathrm{N}$, $\mathrm{P}, \mathrm{K}, \mathrm{Ca}, \mathrm{Mg}$ and $\mathrm{S}$, respectively. The descending order of seed accumulation was $\mathrm{N}>\mathrm{S}>\mathrm{K}>\mathrm{P}>\mathrm{Ca}>\mathrm{Mg}$.

$\mathrm{N}$ was the nutrient with the highest accumulation in seeds. Similar results were obtained with seeds of lettuce (Kano et al., 2010) and broccoli (Magro et al., 2009). Cardoso (2011), in a review including several leafy vegetables, reported that $\mathrm{N}$ accumulation in seeds was always higher than other nutrients. This fact shows the importance of this element $(\mathrm{N})$ in seed composition, generally rich in proteins, besides being a nutrient which is easily redistributed in plant to reproductive parts (Malavolta, 2006).

$\mathrm{S}$ was the second most accumulated nutrient in seeds, confirming the importance of this element in seed formation for Brassicaceae. Magro et al. (2009), reporting the accumulation in broccoli seed, obtained the following order: $\mathrm{N}>\mathrm{S}>\mathrm{P}>\mathrm{K}>\mathrm{Ca}>\mathrm{Mg}$. As main similarity among the studies, the authors highlight sulfur as the second most accumulated nutrient. This is due to a major requirement of this nutrient for Brassicaceae, which remove from the soil substantial amounts of sulfur compared to other macronutrients (Filgueira, 2008). However, this greater need for sulfur has only been observed in seeds of Brassicaceae (cauliflower and broccoli). Just for comparison, in lettuce Kano et al. (2010) obtained the following order of seed accumulation: $\mathrm{N}>\mathrm{P}>\mathrm{K}>\mathrm{Mg}>\mathrm{Ca}>\mathrm{S}$, sulfur being, in this situation, the less accumulated macronutrient. When comparing to the cauliflower plant for commercial production, $\mathrm{S}$ has been the third or fourth most accumulated nutrient in this crop

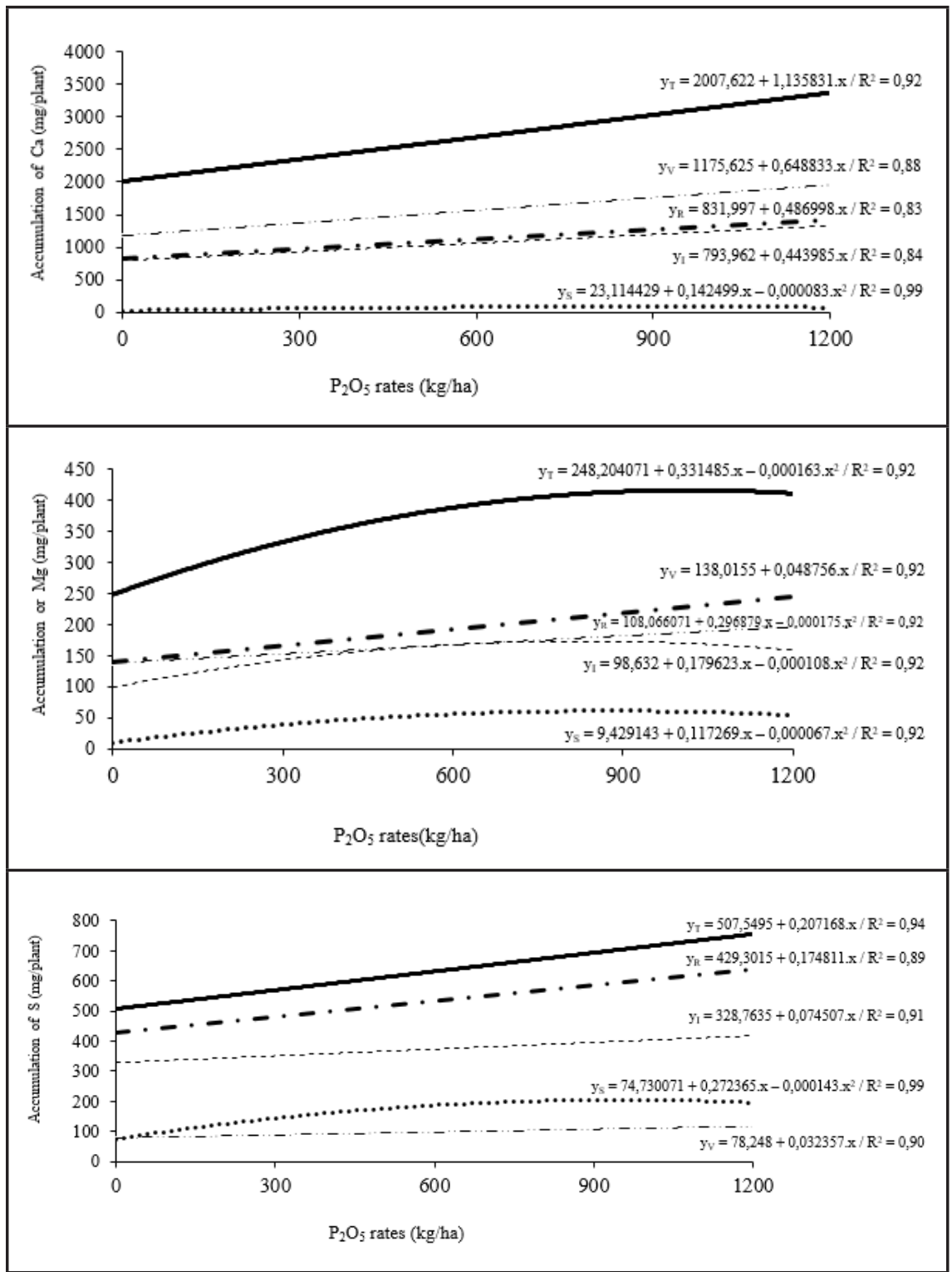

Figure 2. Calcium $(\mathrm{Ca})$, magnesium $(\mathrm{Mg})$ and sulphur $(\mathrm{S})$ accumulation in vegetative part $\left(\mathrm{y}_{\mathrm{v}}\right)$, inflorescence $\left(\mathrm{y}_{\mathrm{I}}\right)$, seeds $\left(\mathrm{y}_{\mathrm{s}}\right)$, total reprodutive parts (seeds + inflorescence) $\left(\mathrm{y}_{\mathrm{R}}\right)$ and in the whole cauliflower plant $\left(\mathrm{y}_{\mathrm{T}}\right)$, depending on phsphorus $\left(\mathrm{P}_{2} \mathrm{O}_{5}\right)$ rates, at the end of cycle \{acúmulo de cálcio $(\mathrm{Ca})$, magnésio $(\mathrm{Mg})$ e enxofre $(\mathrm{S})$ na parte vegetativa $\left(\mathrm{y}_{\mathrm{v}}\right)$, na inflorescência $\left(y_{\mathrm{I}}\right)$, sementes $\left(\mathrm{y}_{\mathrm{S}}\right)$, total reprodutivo (sementes + inflorescência) $\left(\mathrm{y}_{\mathrm{R}}\right)$ e total $\left(\mathrm{y}_{\mathrm{T}}\right)$ na planta de couve-flor, em função das doses de fósforo $\left(\mathrm{P}_{2} \mathrm{O}_{5}\right)$, no final do ciclo\}. São Manuel, UNESP, 2011.

phase (Homa et al., 1969; Furlani et al., 1978; Alves et al., 2011).

$\mathrm{K}$, which was the most accumulated macronutrient in the reproductive part, when flower stems and rests of fruits were included, was the third in the seeds. P was the fourth most accumulated macronutrient in seeds, with values close to potassium which was the third. Carvalho \& Nakagawa (2012) reported that phosphorous compounds are of great importance in several reactions which can be noticed in seeds. Furthermore, phosphorus is a constituent of nucleic acid molecule, which is related to protein synthesis. And also, phospholipids and phosphate sugars, nucleotides and phytin, which is a salt with calcium and magnesium. $\mathrm{Ca}$ and $\mathrm{Mg}$ were the least accumulated macronutrients in seeds, similar to the reported by Magro et al. (2009) in broccoli.

Considering accumulation in the 
whole plant, a linear effect was obtained for $\mathrm{P}, \mathrm{Ca}$ and $\mathrm{S}$ (Figures 1 and 2), with an increase of $51.1,113.5$ and 20.7 $\mathrm{mg} / \mathrm{plant}$ for each $100 \mathrm{~kg} / \mathrm{ha} \mathrm{P}_{2} \mathrm{O}_{5}$, respectively. For $\mathrm{N}$, $\mathrm{K}$ and $\mathrm{Mg}$, quadratic effect was obtained, with maximum accumulation estimated in 3296, 5851 and $417 \mathrm{mg} / \mathrm{plant}$, with rates of 1117 , 937 and $1017 \mathrm{~kg} / \mathrm{ha} \mathrm{P}_{2} \mathrm{O}_{5}$, respectively. The descending order of total accumulation was $\mathrm{K}>\mathrm{N}>\mathrm{Ca}>\mathrm{P}>\mathrm{S}>\mathrm{Mg}$, similar to the order in reproductive part (inflorescence).

Comparing to other authors, in the commercialization stage, results similar to Homa et al. (1969) are observed with this same cultivar, only the last three ones, S, P and Mg being different, with the following descending order: $\mathrm{K}>\mathrm{N}>\mathrm{Ca}>\mathrm{S}>\mathrm{Mg}>\mathrm{P}$. Furlani et al. (1978) and Castoldi et al. (2009) obtained inversion of the two first ones, $\mathrm{N}$ and $\mathrm{K}$, obtaining the following descending order: $\mathrm{N}>\mathrm{K}>\mathrm{Ca}>\mathrm{S}>\mathrm{Mg}>\mathrm{P}$, similar to the obtained by Takeishi et al. (2009): $\mathrm{N}>\mathrm{K}>\mathrm{Ca}>\mathrm{S}>\mathrm{P}>\mathrm{Mg}$, inversion of the two less accumulated ( $\mathrm{Mg}$ and P), whereas Alves et al. (2011) reported, growing in substrate, the following order: $\mathrm{K}>\mathrm{N}>\mathrm{S}>\mathrm{P}>\mathrm{Mg}>\mathrm{Ca}$.

The total maximum accumulation obtained were 3296, 811, 5851, 3170, 417 and $756 \mathrm{mg} /$ plant for N, P, K, $\mathrm{Ca}, \mathrm{S}$ and $\mathrm{Mg}$, respectively. For most nutrients, these values are much higher to the ones reported by Alves et al. (2011) in commercial production of cauliflower, in which they obtained 1870, 540, 3750, 2000, 420 and 1260 $\mathrm{mg} /$ plant for $\mathrm{N}, \mathrm{P}, \mathrm{K}, \mathrm{Ca}, \mathrm{S}$ and $\mathrm{Mg}$, respectively, confirming the greater necessity of most nutrients when the goal is seed production.

When comparing the percentage distribution of macronutrients in the plant at the end of the crop cycle, the authors noticed that only $\mathrm{Ca}$ prevailed in the vegetative part (Table 1). Due to low mobility in plant (Malavolta, 2006), Ca was not redistributed to reproductive parts, which are the main drains of a plant, during their development. According to Grangeiro \& Cecílho Filho (2005), this is due to the fact this nutrient transport occurs preferentially in xylem, with little translocation to fruit development, allowing the accumulation of calcium in the vegetative part rather than in plant fruiting parts.

On the other hand, the two nutrients, which most accumulated in reproductive part, were $\mathrm{N}$ and $\mathrm{S}$. The distribution of macronutrients between vegetative and reproductive parts is directly related to the mobility of these nutrients in plants and to the necessity of the nutrients in each part of the plant. The study observed that $\mathrm{N}, \mathrm{P}, \mathrm{K}$ and $\mathrm{S}$ are the nutrients with larger percentage in reproductive part (Table 1), probably, for being mobile and important in seed formation. In plant, phosphorus, nitrogen and potassium show great mobility, concentrating mainly in flowers and fruits (Malavolta, 2006).

When unfolding the reproductive part in seeds and inflorescence (stems + rests of siliques), the authors notice, clearly, three nutrients which accumulate preferentially in seeds: $\mathrm{S}, \mathrm{N}$ and $\mathrm{P}$ (Table 1). $\mathrm{N}$, besides showing great mobility for redistribution in plant, is also an important component of proteins, which are very important in seed formation, whereas $\mathrm{P}$ is important in composition of phytin, main form of energy storage in seeds (Carvalho \& Nakagawa, 2012). These nutrients ( $\mathrm{N}$ and $\mathrm{P}$ ) are the most important nutrients in seed formation of the majority of species, according to several authors' reports (Cardoso, 2011). Sulphur is important for seed formation in Brassicaceae, and this nutrient was already reported as the second most accumulated in broccoli seeds (Magro et al., 2009).

In relation to potassium, contents in seeds were much lower than observed in vegetative part; similar result was found by Kano (2006) and Kano et al. (2010, 2011) with lettuce seeds. In other words, even with fertilizations, both in planting and top dressing application of potassium, this nutrient was not accumulated in large amount in seeds, only in vegetative part and reproductive stems. $\mathrm{K}$, despite being the most accumulated nutrient by the plant at the end of the cycle, rather than accumulates in seeds, accumulating preferably in flower stems. Probably, seeds may show some mechanism of "filter" in the absorption of nutrients, avoiding, this way, excess of nutrients (known as "luxury uptake"), according to reported by Kano et al. (2010).

$\mathrm{Ca}$ is the nutrient with the lowest percentage of accumulation in seeds; this fact must be related to the low mobility of this nutrient in the plant by phloem (Grangeiro \& Cecílio Filho, 2005; Malavolta, 2006). According to Kano (2006), Ca accumulation in seeds may occur only by absorption and transport during seed maturation, without redistribution from senescent leaves to seeds.

Therefore, the study shows that macronutrient accumulation in a cauliflower plant aiming to seed production differs from plants for commercial production, and that some nutrients accumulate preferentially in seeds, especially N, P and, mainly, S.

\section{ACKNOWLEDGEMENT}

The authors thank CAPES and $\mathrm{CNPq}$ for the scholarships granted and FAPESP for financial support.

\section{REFERENCES}

AKHTAR, MS; OKI, Y; ADACHI, T. 2008. Genetic variability in phosphorus acquisition and utilisation efficiency from sparingly soluble P-sources by Brassica cultivars under P-stress environment. Journal of Agronomy and Crop Science 194: 380-392.

ALVES, AU; PRADO, RM; CORREIA, AR; GONDIM, ARO; CECÍLIO FILHO, AB; POLITI, LS. 2011. Couve-flor cultivada em substrato: marcha de absorção de macronutrientes e micronutrientes. Ciência e Agrotecnologia 35: 45-55.

CARDOSO, AII. 2011. Nutrição e adubação em campos de produção de sementes de hortaliças. In: NASCIMENTO, WM (ed). Hortaliças: tecnologia de produção de sementes. Brasília: Embrapa Hortaliças. p.109-134.

CARVALHO, NM; NAKAGAWA, J. 2012. Sementes: ciência, tecnologia e produção. 5. ed. Jaboticabal: FUNEP. 590p.

CASTOLDI, R; CHARLO, HCO; VARGAS, PF; BRAZ, LT. 2009. Crescimento, acúmulo de nutrientes e produtividade da cultura da couve-flor. Horticultura Brasileira 27: 438-446.

CONTRERAS, S; FARIAS, A; NASCIMENTO, WM. 2014. Produção de sementes de Brassica oleracea. In: NASCIMENTO, WM (ed.) Produção de sementes de hortaliças. Vol. 1. Brasília: Embrapa Hortaliças. p.45-73.

CUNHA, AR; MARTINS, D. 2009. Classificação 
climática para os municípios de Botucatu e São Manuel, SP. Irriga 14: 1-11.

DHAKAL, D; SHAH, SC; GAUTAM, DM; YADAV, RN. 2009. Response of cauliflower (Brassica oleracea var. botrytis) to the application of boron and phosphorus in the soils of Rupandehi District. Nepal Agriculture Research Journal 9: 56-66.

DING, G; YANG, M; HU, Y; LIAO, Y; SHI, L; XU, F; MENG, J. 2010. Quantitative trait loci affecting seed mineral concentrations in Brassica napus grown with contrasting phosphorus supplies. Annalls of Botany 105: 1221-1234.

ELAHI, E; WALI, A; AYUB, G; AHMED, S, HUMA, Z; AHMED, N. 2015. Response of cauliflower (Brassica oleracea L. botrytis) cultivars to phosphorus levels. Pure and Applied Biology 4: 187-194.

FILGUEIRA, FAR. 2008. Novo manual de olericultura: agrotecnologia moderna na produção e comercialização de hortaliças. Viçosa: UFV. 421p.

FURLANI, AMC; FURLANI, PR; BATAGLIA, OC; HIROCE, R; GALLO, JR. 1978. Composição mineral de diversas hortaliças. Bragantia 37: 33-34.

GRANGEIRO, LC; CECÍlIO FILHO, AB. 2005. Acúmulo e exportação de macronutrientes em melancia sem sementes. Horticultura Brasileira 23: 763-767.

HAMMOND, JP; BROADLEY, MR; WHITE,
PJ; KING, GJ; BOWEN, HC; HAYDEN, R; MEACHAM, MC; MEAD, A; OVERS, T; SPRACKLEN, WP; GREENWOOD, DJ. 2009. Shoot yield drives phosphorus use efficiency in Brassica oleracea and correlates with root architecture traits. Journal of Experimental Botany 7: 1953-1968.

HOMA, PM; HAAG, HP; SARRUGE, JR. 1969. Nutrição mineral de hortaliças. II. Absorção de nutrientes pela cultura de couve-flor. $O$ Solo 1: 9-16.

ISLAM, MH; SHAHEB, MR; RAHMAN, S; AHMED, B; ISLAM, ATMT; SARKER, PC. 2010. Curd yield and profitability of broccoli as affected by phosphorus and potassium. International Journal Sustainable Crop Production 5: 1-7.

KANO, C. 2006. Doses de fósforo no acúmulo de nutrientes, na produção e na qualidade de sementes de alface. Botucatu: UNEP- FCA, $112 \mathrm{p}$. (Tese doutorado).

KANO, C; CARDOSO, AII; HIGUTI, ARO; VILLAS BOAS, RL. 2006. Doses de potássio na produção e qualidade de sementes de alface. Horticultura Brasileira 24: 356-359.

KANO, C; CARDOSO, AII; VILLAS-BOAS, RL. 2010. Influência de doses de potássio nos teores de macronutrientes em plantas e sementes de alface. Horticultura Brasileira 28: 287-291.

KANO, C; CARDOSO, AII; VILLAS-BOAS, RL. 2011. Acúmulo de nutrientes pela alface destinada à produção de sementes.
Horticultura Brasileira 29: 70-77.

KANO, C; CARDOSO, AII; VILLAS-BOAS, RL. 2012. Phosphorus rates on yield and quality of lettuce seeds. Horticultura Brasileira 30: 695-698.

MAGRO, FO; ARRUDA, N; CASA, J; SALATA, AC; CARDOSO, AII; FERNANDES, DM. 2010. Composto orgânico na produção e qualidade de sementes de brócolis. Ciência e Agrotecnologia 34: 596-602.

MAGRO, FO; CARDOSO, AII; FERNANDES, DM. 2009. Acúmulo de nutrientes em sementes de brócolis em função de doses de composto orgânico. Cultivando o Saber 2: 49-57.

MALAVOLTA, E. 2006. Manual de nutrição mineral de plantas. São Paulo: Agronômica Ceres. 638p.

MALAVOLTA, E; VITTI, GC; OLIVEIRA, SA. 1997. Avaliação do estado nutricional das plantas princípios e aplicações. 2. ed. Piracicaba: Potafós. 319p.

QUADROS, BR; CORREA, CV; CARDOSO, AII. 2012. Influência de composto orgânico e fósforo sobre sementes de alface. Semina 33: 2511-2518.

RAIJ, B; CANTARELLA, H; QUAGGIO, JA; FURLANI, AMC. 1997. Recomendações de adubação e calagem para o Estado de São Paulo. 2.ed. Campinas: Instituto Agronômico \& Fundação IAC. 285p.

TAKEISHI, J; CECÍLIO FILHO, AB; OLIVEIRA, PR. 2009. Crescimento e acúmulo de nutrientes em couve-flor 'Verona'. Bioscience Journal 25: 1-10. 